UNIVERSITÀ DEGLI STUDI DI ANCONA

DIPARTIMENTO DI ECONOMIA

MULTINATIONAL EXPERIENCE AND THE CREATION OF LINKAGES WITH LOCAL FIRMS.

EVIDENCE FROM THE ELECTRONICS INDUSTRY

DAVIDE CASTELLANI

ANTONELLOZANFEI

QUADERNI DI RICERCA N. 111 
Comitato Scientifico:

Fabio Fiorillo

Alessandro Sterlacchini

- Segretario di Redazione.

Riccardo Lucchetti

- Coordinatore:

Enzo Pesciarelli 


\title{
Multinational experience and the creation of linkages with local firms Evidence from the electronics industry ${ }^{*}$
}

\author{
Davide Castellani** $^{*}$ \\ Università di Ancona \\ and \\ Antonello Zanfei \\ IEFE-Università L.Bocconi, Milano \\ ISE-Università di Urbino
}

\begin{abstract}
The paper focuses on multinational companies' creation of linkages with local firms in the electronics industry. Evidence is drawn from a novel data-set, covering international operations of the top European and US electronics companies, over the 1984-1995 period. Econometric tests are provided to highlight how firms' multinational experience, measured by the extent of their presence in foreign countries, affects cooperative agreements, as opposed to licensing and foreign direct investments. It is highlighted that multinationals' subsidiary accumulation has a positive and significant impact on collaborative linkages with local firms. This contrasts with the predictions of market entry literature, but is consistent with studies on spillovers of inward foreign direct investments. Some implications are drawn both for host economies, particularly LDCs, which are interested in increasing the benefit from multinational presence; and for transnational companies, whose competitiveness in the examined industry largely depends on the ability to develop extensive networks of international collaborations.
\end{abstract}

JEL classification: F23, L22, O33

\footnotetext{
* Some of the ideas developed in this paper have matured through useful discussions the authors had the opportunity to carry out at Iefe-Università Bocconi of Milan, at Urbino University-Dept. of Economics, and within the framework of EMOT Conferences promoted by the European Science Foundation and of the TSERIRD\&P workshops funded by the EU. Special thanks to Ash Amin, John Cantwell , Fabio Fiorillo, Alfonso Gambardella, Mario Pianta, Roberto Schiattarella and Alessandro Sterlacchini for their suggestions. Financial contributions from the Italian National Research Council (CNR) are also gratefully acknowledged.

** Correspondence: Dipartimento di Economia - Università di Ancona - P.le Martelli 8 - 61021 Ancona - Tel. 071-220 7109 - Fax.071-2207 102. Email: davidec@deanovell.unian.it
} 


\section{Introduction}

Multinationals' involvement into collaborative activities with foreign firms has received growing attention in economics literature (Dunning 1995, Cantwell 1995, Duysters and Hagedoorn 1996). Collaborations are broadly defined here as contractual arrangements between transnational corporations (TNCs) and local firms concerning product development, manufacture, or marketing, that are not based on arm's length transactions and fall short of majority ownership ${ }^{1}$. We shall use the terms collaborative activities, cooperative agreements or linkages as synonyms.

Several contributions have highlighted, among other explanatory variables, the role of multinationals' experience of local contexts as a determinant of linkages. Different views have emerged about the impact of this factor. On the one hand, previous multinational experience normally proxied by some indicator of firms' presence outside their home countries - is generally alleged to negatively affect collaborations with indigenous firms in the literature on foreign market entry. The basic idea underlying this view is that joint ventures and non equity agreements with local firms are a means to gather information about, and reduce uncertainty stemming from, foreign markets. It is a costly means because it is associated with high management conflicts and to shirking problems. The greater a firm's experience of the market, the lower the uncertainty, and thus the lower will be the (net) advantages associated to the setting up of alliances (Kogut and Singh 1988, Gomez-Casseres 1989, Mutinelli and Piscitello 1998, Hennart and Larimo 1998).

On the other hand, several empirical studies suggest that the causal link can work in the opposite direction. Suffice here to mention some works on spillovers of inward foreign direct investments, which highlight that multinational experience is a fundamental ingredient of a cumulative process of development. Acquaintance with local contexts will favour the recourse to indigenous suppliers and buyers. As a consequence, externalities will be generated for indigenous manufacturers, potentially improving their performances, and inducing multinationals to set up further linkages with local counterparts. This is probably one of the key mechanisms underlying the increasing recourse to local suppliers by Japanese manufacturers active in Europe (Jetro 1989). Other studies carried out with reference to different countries of origin and destination of FDIs led to similar results (McAlesee and McDonald 1978, Jo 1980, Lim and Pang 1982)

\footnotetext{
${ }^{1}$ The present analysis will be carried out considering the aggregate of contractual arrangements, ranging from long term supply contracts to joint ventures and non equity alliances, as opposed to other forms of international economic activities, such as export, foreign direct investment (which implies complete intra-firm control of production, product development and commercialisation), and the sale of technology through licensing. Distinguishing within this broad range of collaborative ventures is subject matter for future research.
} 
The purpose of this paper is, first, to empirically test the impact of multinational experience on the creation of collaborative linkages with local firms, as opposed to licences, and to the setting up of new, wholly owned (or majority controlled) subsidiaries. We measure multinational experience of local economies by means of the number of pre-existing subsidiaries in a given country, and control for a number of other exogenous sources of heterogeneity. The term " subsidiary accumulation" will also be used to describe our proxy of multinational experience. The test will focus on the electronics industry, which has experienced an extensive recourse to international alliances in the past decades, as reported by a number of empirical investigations, both in absolute terms (Cainarca et al. 1992, D'Orazio et al. 1992), and relative to other high technology industries (Dunning 1993, Duysters and Hagedoorn 1996). Using firm-level data on international operations of the top European and US multinationals active in the electronics industry over the 1984-1995 period, this paper will show that multinational experience of local markets has a positive and significant impact on the creation of collaborative linkages with indigenous firms. This result, which contradicts most of market entry literature, holds both for the generality of recipient countries, and for the LDCs in particular.

Second, we attempt some speculations concerning the basic reasons why multinationals' local experience has such a positive and significant impact on the creation of collaborative linkages in the examined industry. We submit that this positive role has to do with the particular importance learning processes and dynamic competition have in this industry. Technological complexities of manufacturing processes, together with the relevant role played by users as a source of applications experience and of stimuli for product innovation, imply that multinationals will take advantage from an extensive and diversified presence in foreign markets (Steinmueller 1991, Ernst 1997). Subsidiaries accumulated in a foreign market may well constitute "listening posts" to search for, evaluate, and partially exploit new market and technological opportunities. However, many of these opportunities can only be captured by means of collaborative ventures, given time and resource constraints imposed by competition in this industry. From this perspective, subsidiary accumulation and collaborative ventures with local firms can be seen as complementary, with the former providing, inter alia, a more informed basis for the subsequent development of the latter ${ }^{2}$. Therefore, multinational experience will not decrease potentials for collaboration over time, but will enhance cooperation instead.

Consistently with a long tradition that has emphasised the role of backward and forward linkages as a vehicle of economic development (Hirschman 1958, Rodriguez-Clare 1996), our findings have relevant implications for growth strategies of host economies, particularly LDCs. Furthermore, our research can be considered a contribution to a wide

\footnotetext{
${ }^{2}$ Considering complementarity the other way around, that is examining how pre-existing collaborations can favour the subsequent development of wholly owned subsidiaries in the same country (without necessarily substituting for cooperative ventures), is beyond the scope of this work.
} 
stream of literature that has suggested that multinational growth and competitiveness increasingly depend upon the development of extensive networks of relationships with firms endowed with complementary assets (Dunning 1995, Vaccà and Zanfei 1995, Duysters and Hagedoorn 1996).

The structure of this paper is as follows. Section 2 reviews previous studies which have highlighted the role of multinational experience in linkage creation processes, contrasting contributions on market entry strategies with literature on spillovers of inward direct investments in particular. Section 3 describes sources and data. Sections 4 and 5 define dependent and independent variables utilised. Section 6 discusses the results of our econometric exercise with specific reference to the electronics industry, and provides some useful insights for the interpretation of linkage creation processes. Section 7 concludes the paper.

\section{2. $\quad$ Previous research on multinational experience}

The choice of entry mode in foreign markets and, relatedly, of the ownership structure of international operations aimed at penetrating a given market, has attracted considerable interest in both industrial economics and international business literature. One of the most comprehensive frameworks addressing this issue is the one developed by Gomez-Casseres (1989). He suggested that MNEs are likely to prefer jointly over wholly owned ventures when three conditions apply: (1) they need the contribution of a local firm to compete successfully; (2) there are significant costs to the contractual transfer of the local firms' capabilities; and (3) the potential benefits from joint ownership are not outweighed by costs of shirking and of conflicts of interest between partners (Gomez-Casseres 1989 p.9). This way of theorising effectively integrates the transaction costs approach to the choice between market, hierarchy and intermediate governance modes that had already been applied to multinational growth theory (Teece 1986a, Hennart 1988, Buckley and Casson 1988), with at least three other streams of international business literature. First, the studies on asset complementarities as a factor motivating inter-firm cooperation (Stopford and Wells 1972, Teece 1986b, 1992); second, and relatedly, the works on cultural and geographic distance, as a fundamental factor underlying multinational company's need for specific knowledge of foreign markets (Davidson 1980, Kogut and Singh 1988); third, the contributions that focus on organisational costs of inter-firm relationships (Davies 1977, Hladik 1985).

Consistently with this general framework, most works on entry mode strategies assign a relevant, albeit negative, role to multinational experience as a determinant of linkages with local firms. The lack of international experience in general, and of knowledge about specific markets in particular, may cause multinationals to overstate the risks and understating the returns of international markets (Davidson 1980), thus inducing them to adopt a low 
commitment to a new market (Bilkey 1978). The prediction is that multinational involvement will presumably start with exports, then proceed with licensing, continue with more complex inter-firm agreements, and only subsequently lead to FDIs (Johanson and Vahlne 1977, Anderson and Gatignon 1986). Once wholly owned subsidiaries (WOS) have been set up, the perception of uncertainty decreases, and the firm acquires increasing capabilities and knowledge about how to manage foreign operations, and to correctly assess the costs and risks of further wholly owed operations. As a consequence, the greater the experience, the lower the advantages of joint venturing (relative to full ownership) in terms of knowledge access and uncertainty reduction; this will increase the likelihood that such advantages are outbalanced by transaction costs (especially high when tacit knowledge is transferred) and organisational problems (shirking and conflicts) associated to cooperation. In summary, a negative relationship is hypothesised between multinational experience and joint venturing (GomezCasseres 1989, Anderson and Gatignon 1988, Mutinelli and Piscitello 1998, Hennart and Larimo 1998). We shall refer to this as the " entry mode hypothesis".

However, the results of empirical research carried out along these lines are not conclusive and induce us to be cautious in the interpretation of linkage creation processes. Let us briefly review the results that are consistent with the entry mode hypothesis and those that are not.

A few obtain unambiguous evidence of the negative relationship they expected between multinational experience and linkage creation, although the explanatory variable they use for this purpose is not always satisfactory. Gomez-Casseres (1989) uses a binomial logit to test the likelihood of setting up joint ventures (vs. WOS) by 187 US MNEs over the 1975-1985 period. He draws information on individual subsidiaries and on their MNE parents from Harvard's Multinational Enterprise Project. His proxy of " familiarity with host country" was an index (from 0 to 16) based on how often the sample MNEs entered one country before another during 1900-1976. It turned out to negatively impact on joint venturing as he expected. Davidson and McFetridge (1984) test a binomial logit model for the probability of transferring technology through licensing (vs WOS) by 32 US based MNE during the 19451978. Their measure of multinational experience is much simpler that Gomez-Casseres': they use a dummy equal to one if there was at least one affiliate in the recipient country in the year prior to new operation, and find that it has a negative impact on licences (vs. WOS). Mutinelli e Piscitello (1998), examining a sample of operations undertaken by Italian firms in mining and manufacturing industries over 1986-1993, utilise a similar dummy for country experience, integrated by a further dummy indicating whether the earlier operations by the parent company are in "culturally similar" countries. For this purpose they adapted a classification of countries proposed by Ronen and Shenkar (1985), e by Gatignon and Anderson (1988). From their binomial logit model both dummies turned out to negatively impact on joint venturing (vs. 
WOS), although the impact of country experience dummies is not significant for operations directed towards North America.

In a number of cases, the impact of experience variables on joint ventures turned out to be more ambiguous. Kogut and Singh (1988), using a multinomial logit model on 228 entries in the US, find out that previous entry had a negative impact on subsequent joint venturing, but this impact was not significant. Gatignon and Anderson (1988) also use a multinomial logit based on data from the Harvard Project and focus on entry modes in 87 countries between 1960 and 1975. The impact of multinational experience turned out to be positive not only for WOS, but also for lower control modes (minority partnerships, balanced partnerships and dominant partnerships), even though the impact is not statistically significant in the latter group of strategies. Furthermore, one should mention that their measure of experience is very broad (number of foreign entries the MNC has made to date), and does not capture firms' actual knowledge of specific markets. Hennart e Larimo (1998) use a binomial logit model to examine the determinants of Finnish and Japanese entry in the US. In their model, experience is proxied by the number of years of presence of the parent in the host country (the USA): they obtained a negative, but non significant, impact on JV (vs. WOS). While for the Finnish firms of their sample the sign was negative (and significant), as they expected, for Japanese parents experience even turned out to have a positive (albeit non significant) impact.

It thus appears that the extended version of the transaction cost approach proposed by Gomez-Casseres (1989), and more or less explicitly adopted by most scholars addressing the issue of market entry strategies, does not fully explain the role of multinational experience in the linkage creation process. In fact, the view held by these authors on this point is not completely nor unambiguously supported by some of their own evidence.

The need for a closer analysis of how multinational experience affects relationships with local firms is even more apparent when we turn to a different stream of literature. For instance, empirical works on the spillovers of multinational presence provide evidence supporting the opposite view, that multinational experience of local contexts will have a straightforward positive impact on the linkage creation process ${ }^{3}$.

As documented by Dunning (1993 ch.4, 6 and 8), most market seeking FDIs begin with the newly established subsidiaries undertaking simple finishing operations and importing most

\footnotetext{
${ }^{3}$ Among the direct effects of multinational presence, development economics has emphasised the creation of what Hirschman (1958) has defined " backward and forward linkages", identifying the relationships that multinationals can activate with local suppliers and customers respectively. This author suggests that foreign direct investments can create such strong external economies in sectors that supply or buy from them that new investment are undertaken to exploit them (Hirschman 1958 p.205-206). The rather extensive empirical literature on these processes has focussed mainly on backward linkages and is most often based on case studies on specific multinationals that have entered a given country, or on particular industries and countries. These studies often contain valuable "circumstantial evidence" of how spillovers are generated through linkages, and about the factors facilitating the creation of linkages (and of related spillovers) (cf. Dunning 1993, and Blomstrom and Kokko 1997 for extensive reviews of these empirical works).
} 
of their inputs. Gradually, as and when indigenous technological and manufacturing capacity improves and becomes more competitive, the local content ratio increases. For instance, Japanese manufacturing affiliates in Europe imported $37.2 \%$ of the value of their components in 1988, while this ratio was much higher $(52.6 \%)$ at the start of their European operation in the late 70's and early 80's (JETRO 1989). Some firm level evidence is even more striking. In 1987, the first year Nissan began its operations in the UK, only $40 \%$ of the sales value of automobiles was produced locally; while the ratio had grown to 75\% in 1991 (Dunning 1993 p.449). McAleese and McDonald (1978) and Jo (1980) have studied the behaviour of multinationals in Ireland and South Korea, and found that their propensity to import from abroad significantly decreased with the age and experience of subsidiaries. For instance, McAleese and McDonald (1978) found that, in all of the six Irish manufacturing sectors which they considered, the expenditure for local products had significantly risen over the 1966-74 period.

Of course the patterns we have briefly recalled might also have been determined by other factors, including host countries' pressures to increase local content. Furthermore, the works we have considered do not test the impact of country experience using multivariate techniques with reference to large samples of firms. However, they appear to offer rather systematic evidence of the positive impact of this variable on linkage creation, with reference to a wide variety of sectors and countries of origin and destination of FDIs. One is thus induced to believe that, most probably, foreign manufacturers in the examined industries and countries have increased their ability to interact with local suppliers, have invested to increase their capabilities, and found it more and more convenient to buy locally. In the cases we have briefly recalled, firms' experience of a foreign country seems to have actually decreased uncertainty about its market and institutional conditions, as predicted by market entry literature. However, differently from a further prediction of that literature, reduced uncertainty has not determined a lower recourse to cooperation: it has presumably created mutual acquaintance, reliability and trust that are better conditions for further knowledge exchanges and collaboration.

To conclude this section, we suggest that testing the relationship between multinational experience and linkage creation is worthwhile. The question of whether and why the former has a negative or positive impact is open.

\section{Sample and data}

We shall test the impact of multinational experience on linkage creation with reference to a sample composed by all the European and North American manufacturers of computers, telecommunications equipment, semiconductors and other electronics products listed by Fortune 500 (1990 classification). AT\&T, which was classified by Fortune as a Service 
company, was also included in our list. Thirteen companies are European, nineteen are from North America (including 1 Canadian). Four of these companies have their core business in telecommunications, 13 in computers, 3 in semiconductors. Twelve firms have their core businesses in other electronics or related sectors, but do have some significant involvement (no less than $10 \%$ of total sales) in at least one of the three main electronics equipment industries mentioned above.

Data on international operations of these firms in the 1984-1995 period are drawn from $A R G O$ (Agreements, Restructuring and Growth Operations), a database which uses information from Predicasts $F \& S$ Index. From this source we organised the available information on international ventures by firm, country of origin and destination, type and content of operations, and SIC codes identifying the main industrial activities in volved. We counted the number of foreign direct investments, of collaborative alliances and of licensing agreements of our sample firms in each destination country. See appendix 1 for a description of the database and list of companies included, organised by country of origin and core business. As the sample multinational enterprises are the largest in the electronics markets, we deemed it reasonable to focus on their operations involving companies not belonging to the same list of firms, i.e. we only considered counterparts which are, roughly, external to the core international oligopoly. This should help us separating the processes we are particularly interested in - i.e. the creation of linkages with firms active in the markets where multinationals have entered - from other patterns of international organisation, such as global strategic alliances that are often set up among the largest companies in a given industry.

We ended up with a total of over 1700 international operations involving our 32 firms in 58 different countries for which we have data on control variables that are specified in section 4. Apart from the US, Canada and Japan, the country list includes 17 Western European countries, 7 Eastern European, 14 of Africa and Middle East, 11 of South East Asia and Oceania ${ }^{4}$.

We complemented these data with the number of "first and second level" international subsidiaries of the 32 firms in the identified countries and sectors, as recorded in Predicasts Company Thesaurus, Annual Edition 19835. "First and second level" means that we considered the number of affiliates reporting directly to the parent company, as well as subsidiaries that were eventually created by these foreign affiliates in the same country in which

\footnotetext{
${ }^{4}$ Developed Countries: Australia, Austria, Belgium, Canada, Denmark, Finland, France, Germany (West), Greece, Ireland, Israel, Italy, J apan, Luxembourg, Netherland, New Zealand, Norway, Portugal, South Africa, Spain, Sweden, Switzerland, Turkey, U.S.A, United Kingdom; Less Developed Countries:Algeria, Argentina, Brasil, Bulgaria, Cina, Cyprus, Czechoslovakia (Former) , Egypt, Hong Kong, Hungary, India, Indonesia, Iraq, Ivory Coast, J amaica, Malaysia, Mexico, Morocco, Niger, Philippines, Poland, Puerto Rico, Romania, Saudi Arabia, Singapore, South Korea, Taiwan, Thailand, Tunisia, United Arab Emirates, USSR (Former), Venezuela, Yugoslavia (Former).

${ }^{5}$ We adopted the classification scheme utilised by Gambardella-Torrisi (1998) for an analysis based on the same sample of firms. We are grateful to Daniele D' Alba for collecting and organising data on subsidiaries.
} 
they are active, or elsewhere. We ended up with more than 900 subsidiaries, of which over two thirds are " second level" (affiliates of foreign affiliates).

Econometric elaborations were conducted controlling for other variables obtained from different sources. These are specified in section 5 and described in a detailed way in Table 1 .

\section{Dependent variables and econometric model}

Econometric investigations were carried out using three different dependent variables: international agreements $\mathrm{AG}_{\mathrm{ik}}$, licensing $\mathrm{LIC}_{\mathrm{ik}}$, and foreign direct investments $\mathrm{FDI} \mathrm{ik}_{\mathrm{ik}}$. International agreements $\left(\mathrm{AG}_{\mathrm{ik}}\right)$ are defined as the sum of international joint ventures and non equity agreements, involving company $i$ (identifying our 32 sample firms) and at least one other firm originating from country $k$. By definition, country $k$ must be different from the one from which firm $i$ originates.

Licenses $\left(\mathrm{LIC}_{\mathrm{ik}}\right)$ are defined as transactions of patented technology from firm $i$ to foreign parties active in country $k$, and $\mathrm{FDI}_{\mathrm{ik}}$ as the number of foreign direct investment operations.

We consider international agreements $\left(\mathrm{AG}_{\mathrm{ik}}\right)$ as the closest proxy of what is defined as "linkages with local firms" in the literature on spillovers of multinationals ${ }^{6}$. It is more comprehensive and relevant than the aggregate of joint ventures, that is most frequently utilised in international business studies, and in entry mode literature in particular. Unfortunately our data do not permit to distinguish between backward and forward linkages. Furthermore, we are unable to detect "net linkages", that is relationships with local firms, net of activities that have been eventually displaced by multinational presence.

Regressions were run also using $\mathrm{LIC}_{\mathrm{ik}}$ and $\mathrm{FDI}_{\mathrm{ik}}$ as dependent variables, which we identify as the closest proxies of pure market transactions and of wholly owned (or majority control) operations.

Our dependent variables are obtained as the cumulative number of operations (however defined according to the specifications above) developed by firm $i$ with other company(ies) of country $k$ over a twelve year period (from 1984 till 1995). For instance we defined AG8495 ik as the cumulative number of international alliances of firm $i$ with partner(s) of country $k$ over the 1984-1995 period. Therefore, they are, by construction, discrete and non-negative. In addition, more than $80 \%$ of observation take the value zero.

When variables have this nature, we can "improve on the least squares and the linear model, with a specification that accounts for these characteristics." (Greene 1997, p. 933). A class of econometric models has been developed just for this purpose: the models for event

\footnotetext{
${ }^{6}$ According to Lall (1978 p.216-217), linkages can be defined as " those relationships between TNCs and domestic enterprises trading with them that have led the latter to respond, positively or otherwise, to technological, pecuniary, marketing or entrepreneurial stimuli provided by the former. A 'linkage' in this sense is clearly different from a normal transaction in a competitive market; it refers essentially to the externalities created for domestic industry by the entry of TNC investment"
} 
counts $^{7}$. Among the count data models, the negative binomial is particularly suited for our purpose $^{8}$, since it accounts for the of cross-section heterogeneity that normally characterises microeconomic data. For the analytical formulation of the regression model, of the loglikelihood function utilised for estimation, and of elasticity that can be derived from the estimated parameters, see Appendix 2.

The number of observations never falls below 1056 (when the attention is restricted to operations with LDCs as destination countries), and can be as high as 1824 when all the sample firms, countries and sectors are considered. Positive observations range from 103 (in the case of LICs), to 199 (in the case of FDIs) and to 346 (in the case of AGs).

\section{Explanatory and control variables}

We tested, with controls, the impact of our firms' multinational experience in a given country $k$ on their own recourse to AGs, FDIs and LICs in the same country over the examined period. See table 1 for a description of dependent and independent variables utilised in our regressions, and tables $2 \mathrm{a}$ and $2 \mathrm{~b}$ for descriptive statistics.

\subsection{Multinational experience}

This variable was proxied by $\mathbf{S U B S 8 3}_{\mathbf{i k}}$, the number of "first and second level" subsidiaries of firm $i$ in country $k$ in 1983, i.e. at the beginning of the international growth phase we intend to analyse. This measure is certainly more accurate than a simple dummy, as frequently used in the literature (cf. above, section 2) and closely resembles the one utilised by Gomez-Casseres (1989), who produced an index of "familiarity with host country" based on how often his sample's MNE entered one country before another in a given period. We consider this choice more arbitrary than counting the overall number of subsidiaries, which exactly measures how extensive a MNE's internal network of affiliates is.

Unfortunately we do not presently have measures of "age" of subsidiaries, which would obviously represent important complements to the analysis of multinational experience. To our knowledge, only one very recent study (Hennart and Larimo 1998) produced regressions using the number of years of presence of affiliates in the host country, an effort that was eased by the fact that they considered only one destination country, for which plenty of statistics are available (the US).

\footnotetext{
${ }^{7}$ There are now many applications of count data regression models which use cross-section, time series or panel data. A classical example is the relationship between $R \& D$ and the number of patents of a firm examined by Hausman et al . (1984). For an extensive review of the theory and applications of this class of models, see Cameron and Trivedi (1998).

${ }^{8}$ In tables 3 and 4, we present also the results of a likelihood ratio test for the Poisson vs the Negative Binomial specification. The null hypothesis is rejected at the $5 \%$ confidence.
} 
We neither have information on the "composition" of TNCs' web of subsidiaries, in terms of size and specialisation, which are relevant aspects of TNC presence. Extending these parts of our analysis is subject matter for future research.

Given these limitations, in the light of the discussion above (section 2), the " entry mode hypothesis" would imply that SUBS has a negative impact on collaborative linkages (AGs) and a positive impact on FDIs. Although this literature does not usually distinguish between different contractual modes, the most straightforward implication of this theory would be that also LICs be negatively affected by SUBS. In fact, it can be considered a tool for reducing uncertainty about local markets, whose role would be quickly overcome by multinational presence, much like AGs, and even more so (see Davidson and McFetridge 1984 for similar conclusions). Nevertheless, it is a means to carry out transactions of codified and patented knowledge, which is subject to lower organisational problems than AGs; this would justify some uncertainty about the impact of SUBS on LICs in the entry mode hypotheses.

In order to control for further exogenous sources of heterogeneity we introduced the following control variables.

\subsection{Company variables.}

One of our firm level control variables accounts for a different, albeit related, aspect of multinational experience, i.e. companies' exposure to foreign markets, as measured by the number of countries in which they had at least one affiliate in 1983 (MULTI $\mathbf{M}_{\mathbf{i}}$ ). This index of multinationality was used by several authors, among which Kogut and Singh (1988) and Caves and Mehra (1986) and was usually negatively related to joint venturing. This variable should be subject to much the same type of considerations that we suggested for SUBS. However, this variable should have less direct an impact on linkages in a given country and more on the propensity to cooperate as a whole.

R\&D intensity (RD_INT $\mathbf{i}$ ), calculated at the firm level, should account for the innovativeness of companies, a factor that is often considered in the literature as a determinant of international production (Pearce 1997), and of joint ventures in particular (Hennart and Larimo 1998).

A dummy variable was introduced for US companies, $\mathbf{D U S A}_{\mathbf{i}}$, to account for differences in institutional and market size conditions, and other factors between the North American and European firms. We also controlled for the size of firms in terms of their global (consolidated) sales, $\mathbf{S A L}$.

\subsection{Recipient country variables}

The average education attainment (in terms of schooling years) in the total population over 25 in country $k$ is introduced as a measure of human capital endowments of host economies $\left(\mathbf{H U M A N}_{\mathbf{k}}\right)$. This measure was introduced by Barro and Lee $(1993,1996)$ and has the advantage of focusing on the stock of human capital. Other measures utilised in the 
literature either focus on current flows of human capital (e.g. school enrolment ratios) or do reflect specific skill levels (e.g. adult literacy rate or secondary education attainment ratio). In international economics literature, Borensztein et al. (1998) utilise the same specification we do in their analysis of the effects of foreign direct investments on economic growth. There is a general agreement in the literature on multinational spillovers that the level and efficiency of host countries' infrastructures, especially education and training of local workforce, should positively impact on linkage creation (Dunning 1993).

Per capita Gross Domestic Product $\left(\mathbf{G D P}_{\mathbf{k}}\right)$ is taken into account to control for the degree of development of host countries. This measure should also capture, inter alia, the effect on AG of the advancement of other infrastructures (different from education and training institutions, which are more directly taken into account by Human). It also accounts for the richness of markets as an attractor of international operations (Zejan 1990).

We also controlled for the size of local market in terms of total population, $\mathbf{P O P}_{\mathbf{k}}$, i.e. a measure of what we may consider the "potential" market of a country, especially when considered "in combination" with per capita GDP (Kobrin 1976).

The pace of economic development was measured by simple annual growth rate of per capita GDP over 1980-1987 (GGDP $\left.\mathbf{G}_{\mathbf{k}}\right)$.

Furthermore, we took account of trade barriers using $\mathbf{O W T I} \mathbf{I}_{\mathbf{k}}$, i.e. the so called "Own-import weighted tariff rates on intermediate inputs and capital goods", as specified by Barro and Lee (1993). International production abroad, via FDI or AG, are traditionally considered a strategy to bypass trade barriers (cf. inter alia, Gomez-Casseres 1989), even though this argument has received mixed support from evidence.

Finally, a control was introduced for the sector composition of the recipient countries in terms of the share of electrical machinery value added as a percentage of value added in manufacturing $\left(\mathbf{E V A}_{\mathbf{k}}\right)^{9}$. Gomes-Casseres (1989) and Davidson and McFetridge (1984) utilise a similar measure for their analyses, referred to a broader set of industries, to account for local firms' ability to supply valuable manufacturing capabilities to multinationals entering a market.

\subsection{Relation specific country variables}

In order to further control for exogenous sources of heterogeneity, we included a few variables that capture different aspects of the relationship existing between the country of origin, $n$, of firm $i$, and the destination country, $k$.

A variable was introduced to account for a home country specific feature of multinational experience, other than the ones identified by SUBS and by MULTI. We utilised for this

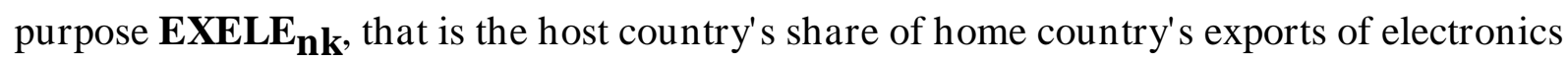
(the ratio between exports of electronics products from the country $n$ of origin of firm $i$ to country $k$, and total electronics exports of the country $n$ ). Kobrin (1976) utilised much the

\footnotetext{
${ }^{9}$ Wage and Value added data were kindly supplied by Christine Gaignebet of ILO.
} 
same indicator in his analysis of the geographical distribution of US manufacturing FDIs (in his case, it was the host country's share of total US exports). We suggest that not only FDIs, but also AGs can be positively influenced by prior export penetration. The idea is that international operations may be affected by a sort of bandwagon effect, determined by the fact that other electronics firms from the same home-country have penetrated that market already. This home-country trade experience can influence, in a very general way, the knowledge a firm can be expected to have about a given country. Furthermore, one may expect that a high EXELE should signal that economic agents in the host country are somehow acquainted with the host country's product characteristics, a factor that could reduce communication costs between the firm $i$ and local companies. Again, if the "entry mode hypothesis" were adopted, this variable should be expected to have a negative impact on linkage creation, for much the same reasons that apply to SUBS and NUMK.

A rough measure of geographic distance between firm $i$ 's country of origin and the host country (DISTANCE $\mathbf{n k}_{\mathbf{n}}$ ) is utilised to account for transportation costs (Papanastassiou and Pearce 1990) and, relatedly, for the costs of monitoring intra-firm activities (cf. Davidson and McFetridge 1984, whose indicator of geographic distance is very similar to the one adopted in this paper). According to entry mode literature, this variable can thus be expected to negatively impact on FDI, and positively on other less structured forms of international organisation of production.

We also utilise a proxy of cultural distance (CULTDIST nk $_{\mathbf{n}}$ ). Like other international business studies, we adopted the classification proposed by Hofstede (1980), which is calculated as a corrected arithmetic average of the deviation of home scores from the corresponding score for the host country, based on four dimensions of cultural identity: power distance, uncertainty avoidance, individualism and masculinity. Among others, Kogut and Singh (1988) and Mutinelli and Piscitello (1998) adopt the same measure and find that it positively affects joint venturing (vs. WOS).

Finally, the average wage differentials between firm $i$ 's country of origin and country $k$ in electronics industries (WAGELE $\mathbf{n k}_{\mathbf{n}}$.) is introduced to account for labour cost factors. When the ratio is grater than one, we then interpret that wages are higher in the host country than in the home country. The same indicator was utilised by Swedenborg (1979). Much like trade barriers, wage differentials (WAGELE greater than 1) are traditionally considered to negatively affect multinationals' production decisions, especially in LDCs. However, it is a spurious measure, which can also capture the qualitative level of workforce.

\section{Discussion of results}


Regressions yielded the results reported in tables 3 and 4, which will be discussed below ${ }^{10}$. We shall contrast these results to the "market entry view" illustrated in section 2.The discussion of results should improve our understanding of the role of multinational experience in the electronics industry's international growth strategies. Some insights will be suggested, which might provide a useful contribution to the construction of a framework, that can at least partially integrate the market entry mode theory, for interpreting linkage creation processes.

\subsection{Alternative modes of organising transactions with local firms}

Table 3 presents our results for dependent variables AG8495 ${ }_{\mathrm{ik}}$, FDI8495 $5_{\mathrm{ik}}$, and LIC8495 ${ }_{\mathrm{ik}}$, that is, respectively, collaborative modes, full integration (hierarchical) modes and market modes of organising transactions with foreign counterparts. Contrary to the predictions of entry mode literature, AGs turn out to be positively and significantly affected by our measure of multinational experience (SUBS). The sign is also positive but not significant when FDIs are used as a dependent variable. In the case of licenses the impact is even less significant.

No substitution effect can be identified between subsidiary accumulation and linkage creation in the examined industries. Accumulating experience about a given country, by means of an extensive network of subsidiaries in that country, does not increase the likelihood of control modes of governance relative to collaborative modes.

Electronics thus appears to represent an important " deviation" from the rule suggested by most of the " market entry" literature. Particularly, the extended version of the transaction cost approach proposed by Gomez-Casseres (1989), and more o less explicitly adopted by most scholars addressing the issue of market entry strategies, does not help explaining the role of multinational experience in the linkage creation process in this case. This theory has received shaky support from evidence on this specific, but crucial, aspect. It receives a straightforward rejection from our evidence concerning this aggregate of industries.

This (negative) test is quite relevant as electronics has given one of the most outstanding contributions to international growth operations and to international alliances in particular, over the examined period. According to UNCTAD (1997), 32 out of the 100 top multinationals are active in electronics, the largest single group of firms recorded in the list in 1995.. With specific reference to collaborations, Duysters and Hagedoorn (1996) show that the largest share of the nearly 10,000 cooperative agreements (over 4600 of which are technical alliances) involving some 3500 different parent companies active in high technology industries, as reported by the MERIT-CATI over the 1980' s, is represented by collaborative ventures in the broad field of Information Technology. These account for more than $40 \%$ of the total

\footnotetext{
${ }^{10}$ In tables 3 and 4 we present the estimated coefficients $\hat{\beta}_{j}$ 's. These will be sufficient for most of our discussion. In order to obtain elasticities, one needs to multiply the coefficient by the sample mean of the independent variable (see the descriptive statistics in tables $2 \mathrm{a}$ and $2 \mathrm{~b}$, and Appendix 2 for the interpretation of estimates).
} 
number of alliances they counted (as opposed to less than $25 \%$ for biotechnology, and $15 \%$ for new material technology).

It is by now widely acknowledged that this pattern of international growth, which particularly relies upon the development of international linkages, has much to do with the nature of learning and of competitive processes in the examined industries. Dunning (1993 p.452) has placed the issue in the proper perspective: "within the electronics sector the nature of the production process, the complexity of technology, the opportunities for scale economies and the rapidity with which changes in technology or customer preferences take place, have all led to more inter-firm linkages, mainly it seems because purchasing firms prefer to devote their own resources to technology development and marketing efforts, rather than to backward integration". This view could be specified with reference to the different industries belonging to this aggregate ${ }^{11}$. However, an important generalisation that can be made is that electronics industries have all been affected by a plethora of new opportunities, generated by technological progress and reinforced by learning by doing and by using, that increased the incentives for manufacturers to search for, and gain access to, both technical skills and applications abilities wherever available. For these purposes, international alliances represent a key strategy, given technical and market complexities and time constraints imposed by competition in these industries and in those using electronics devices as inputs. As Ernst (1997) has observed in his study of international production networks in the electronics industry: " the epicentre of competition has shifted to $\mathrm{R} \& \mathrm{D}$ and other forms of intangible investment that are necessary to enhance a firm's speed of response to changes in technology, markets and regulations. In short, what really matters are the substantial investments required in the formation of a firm's technological and organizational capabilities".

\subsection{A tentative generalisation}

This view is consistent with a more general understanding of strategic alliances as "an attractive organisational form for an environment characterised by rapid innovation and geographical organisational dispersion in the sources of know how" (Teece 1992 p.20). According to this view, the need for a timely and effective knowledge access may well overcome short term, static (transaction and organisational) cost minimisation. This view has recently extended from the general theory of the firm (Cyert and March 1963, Nelson and Winter 1982, Chesnais 1996), to the more specific domain of multinational growth theory (Cantwell 1991, Kogut and Zander 1993, Dunning 1995).

\footnotetext{
${ }^{11}$ See Steinmueller (1992) for a comprehensive study of th evolution of semiconductor business and of th emerging specialisation opportunities stemming from the interaction with large users; Flamm (1989) and Zanfei (1993) for a thorough analysis of the changing technology and institutional environment in which computer and telecommunications manufacturers are active, leading them to a growing involvement into crossborder alliances.
} 
We suggest that dynamic efficiency considerations, particularly those related to knowledge accumulation and exploitation, are a key missing factor in the " market entry literature" explanation of linkage creation processes. This missing factor helps understanding the important "deviation" from the rule, represented by the electronics industry, as illustrated by our data.

From this perspective, the role of multinational experience can also be re-considered. In fact, consistently with a more general view of complementarity between internal and external competence accumulation ${ }^{12}$, the development of an extensive network of subsidiaries located in different countries can be identified as a fundamental asset increasing a firm's capacity to absorb knowledge, wherever it may be located. As Cantwell (1995, pp. 157) has stated it: "Technology leaders are now ahead ... in the development of international intra-fim networks to exploit the locationally differentiated potential of foreign centres of excellence. These networks are internal to the firm in order to build upon or extend its core technological competence through an internally coordinated learning process, but they are complementary to external inter-firm networks whose role is the exchange of knowledge and occasionally cooperation in learning through technology-based joint ventures". Even more explicitly, Sachwald (1998) describes the recent evolution of international operations in the automobile industry, as a process of cumulative learning in which the first step is a foreign direct investment, paving the way to collaborative learning from local contexts: " The methods of production which Japanese carmakers had developed relied on specific know-how and routines. The latter being difficult to transfer, Japanese firms had first been prone to set up greenfield sites as a first choice way to produce in the US. Cooperative agreements were used as complements to speed up learning on local practices and reduce risks." (p. 219).

Our evidence on the electronics industry is consistent with this representation of linkage creation patterns in the automobile industry. More generally speaking, one may speculate that multinational experience favours a gradual and cumulative involvement of the firm that does not exclude the recourse to collaborative ventures, as predicted by market entry literature: it may reinforce it. In the beginning, firms can be expected to develop a number of informal and formal relationships with local institutions and firms. These may well be quasi-market transactions, to start with. For instance, in the case of a manufacturing subsidiary, one can imagine some minor complexities in the relationships with suppliers of inputs and/or with resellers of manufactured goods; such complexities will require the development of some collaborative activities along with the usual market transactions (Amin 1993 p.283). Local activities will also imply some experience of indigenous rules, norms of conduct, and values

\footnotetext{
${ }^{12}$ See Cohen and Levinthal (1989) for a modeling of these complementarities; Rosenberg (1990) for an analysis of the interdepencies between in-house basic research and access to external sources of economically useful knowledge conducted through historical examples referring to different industries; Arora and Gambardella (1990), and Malerba and Torrisi (1992) for an application of a similar analytical framework to biotechnology and to the software industry respectively.
} 
which influence the behaviour of economic agents, including labour force and capital market institutions (Rosenzweig \& Nohria 1994). As the experience of local contexts proceeds, the co-operative content of relationships can be expected to increase ${ }^{13}$. In fact, the subsidiary's acquaintance with local contexts, habits and culture, is likely to increase the subsidiary's ability to interpret and absorb tacit, context specific knowledge their counterparts are endowed with (Vaccà 1994). Furthermore, local subsidiaries' growing knowledge of the local environment not only reduces uncertainty about market characteristics (thus reducing the need for collaborations, according to the market entry literature); it will also reduce uncertainty concerning the likely behaviour of indigenous counterparts. This will significantly increase their ability to select partners according to their actual reliability and complementarity, and according to the value of their potential contribution (Bureth et al. 1997). As a consequence, subsidiaries will also enhance their ability and effectiveness at capturing new technological opportunities, and at adapting existing knowledge to local uses. This will in turn improve their reputation and credibility as partners of indigenous firms and institutions. Altogether, this process will increase trust, and pave the way to further co-operation.

In summary, the examined evidence highlights that, to the extent that learning and dynamic efficiency considerations play an important role, as they definitely do in the electronics industry, linkage creation effects associated to multinational experience tend to overcome the opposite, negative incentive to cooperate that is predicted by market entry literature.

\subsection{Licensing}

The results we obtained for LICs in Table 3 are not so sound as when using AGs and FDIs as dependent variables, for a number of reasons. From a merely statistical point of view, they rely on a much lower number of positive observations (117) and on very small mean and variance of the dependent variable (see Tables $2 \mathrm{a}$ and $2 \mathrm{~b}$ ). The Chi-square statistic, for testing the hypothesis that the the parameter estimates are all equal to zero, is illustrative in this respect: although we still reject the null hypothesis at $95 \%$ confidnce level, the statistics in this case take a much lower value than for the regression of AG and FDI.

However, the fact that subsidiaries appear to have no significant impact in the development of licensing activities further enriches our view of the industry. On the one hand, this result suggests that firms need no specific knowledge of the market in order to commercialise technology through licenses. Knowledge that can be transfered via licensing agreements is relatively mature and largely codified (Hennart 1988 p.221), and this reduces the

\footnotetext{
${ }^{13}$ There is some correspondence here between our line of argument and the one developed by other authors who emphasize that historically determined networks of personal and social relationships among economic agents influence the organization of their transactions. Some scholars name these networks of personal and social relationships with the term embeddedness. Granovetter (1985 p.503) suggests that, where such networks are stable and do not generate occasions for malfeasance and conflict, we should expect pressures towards vertical integration to be absent. This insight was developed and applied to the study of international business especially by scholars of the " Swedish school" (cf. for instance Andersson and Forsgren 1995).
} 
need for a local presence of the MNE to help in the development, adaptation and commercialisation of technology according to market characteristics. On the other hand, very few such transactions can occur in the electronics industry. In fact, technology changes rapidly, its development requires extensive system integration and intensive exchanges of information and know how between manufacturers and between users and producers; furthermore, many technological developments that are relevant to the industry cannot be protected by well enforced patents (as in the case of software). All these circumstances imply that such technology is less amenable to transfer via license (Mowery 1988 p.6).

\subsection{Impact of control variables}

A few considerations should be made on control variables. First, variables we have introduced to capture other, more generic experience factors, such as the number of foreign countries covered (MULTI), and the host country's share of home country's electronics exports (EXELE) do corroborate the view we are supporting in this paper. Both of them have a positive and significant impact on collaborative linkages (EXELE positively and significantly affects all three modes of organising transactions, but has a much stronger impact on AGs). This further reinforces the idea that experience accumulation, by increasing a firm's ability to perceive and evaluate opportunities, increases the need for collaborative strategies to exploit them. Cultural distance (CULTDIST) has a positive impact on collaboration and a negative one on FDIs as predicted by most contributions in international business.

When considering these, more general factors influencing linkage creation, we find further evidence of the fact that the entry mode story only partially applies in the examined industry: consistently with this literature, cultural distance and lack of knowledge about markets seems to favour agreements as opposed to $100 \%$ investments; different from the predictions of this theory, once subsidiaries enter a market, the experience they accumulate and the information they gather does not reduce the benefits from cooperation. On the contrary, firms are most likely to utilise the new information to increase their involvement through collaborative agreements.

Human capital (HUMAN) and host country's industry composition (EVA) both positively and significantly affect collaborative linkages. This has important implications for host countries' government policies, which we shall address with more specific reference to LDCs. Wage differentials (WAGELE) do not significantly impact on any governance mode, even though the sign is negative, as expected, in the case of FDIs.

Finally, trade barriers (OWTI) do not significantly affect either strategy. We could notice that the sign is negative in the case of both AGs and FDIs. The fact that the impact is negative, albeit non significant, seems to confirm the argument put forward by Dunning (1993 p.165): "In a global economy increasingly characterised by intra-industry and intra-firm trade, 
it is the absence, rather than the presence of these restrictions which are more likely to stimulate the further internationalisation of MNE activity".

\subsection{The case of $L D C s$ as recipient countries}

Interestingly enough, some similarities and differences emerge once we examine patterns of linkage creation with specific reference to a sub-sample represented by international operations with LDCs as destination countries. Table 4 shows a very similar story when considering the impact of subsidiary accumulation on linkage creation in the LDCs. SUBS83 has a generally positive impact on the creation of all types of linkages, but estimates are statistically significant only in the case of AGs (the effect on LICs is the smallest and least significant). The linkage enhancing effect of country experience generated by subsidiary accumulation appears to be confirmed in the case of LDCs too.

Important differences emerge when we examine the other independent variables.

The first point to be made here is that, while EXELE and MULTI still play the role we had observed in the whole sample case, the other "relation specific country factors", CULTDIST and DISTANCE play a completely different role in this case. The former completely loses significance in the case of AGs, whereas it positively and significantly impacts on FDIs; the latter, even reverses its sign, and turns to negative for AGs. It thus appears that multinational experience, considered both at the firm specific level (SUBS and MULTI) and the country level (EXELE), still has the linkage enhancing role that we have discussed earlier. By contrast, diversities and distances between countries do not favour cooperation in this case. Both predictions of "entry mode" literature are rejected when LDCs are considered as recipient countries: it is not only true that, contrary to that literature, subsidiaries generate new opportunities for collaboration; but, again, contrary to that literature, the lack of knowledge and the geographic distances between countries do not encourage linkages as an uncertainty reducing mode.

A possible interpretation of this result is that most LDCs are not attractive enough in terms of infrastructures, local competencies and manufacturing abilities, to encourage high technology companies to collaborate with local firms, unless some support is given to them at one or more of the following three levels. First, some support may derive from the fact of having a network of subsidiaries extensive enough to help the parent company "picking the cherries" among the potential suppliers and users in the local markets. This is apparent from the positive and significant impact of SUBS in this case too. Second, further countervailing forces, may increase the attractiveness of LDC markets, when more " traditional factors" are at work, such as high trade barriers or wage differentials. Notice however that high trade barriers may attract collaborations and not FDIs (nor licensing); confirming that cooperative ventures may be more flexible, exploratory means to enter a protected market. By contrast, low wages 
in the host country attracts FDIs, as largely expected, in the case of LDCs ${ }^{14}$. In the case of AGs wages continue not to have a significant impact, presumably because human capital and skill intensity considerations tend to prevail as an attractor for foreign business (see below). Third and finally, support may come from host countries, which can both encourage inward foreign direct investments, in order to pave the way to linkage creation effects; and invest massively and carefully in human capital formation, in infrastructures, and in manufacturing abilities that are badly needed to make the country attractive for international business. The importance of these determinants of linkage creation is basically captured by the very high and significant role of HUMAN in attracting linkages. This last point should be emphasised: HUMAN was barely significant as a determinant of linkages in the whole sample case; it is now very strong and significant, in the case of LDCs. This presumably signals that when considering LDCs as recipient countries, human capital investments can constitute an effective long term policy attracting foreign capital and favouring linkage creation processes.

\section{Conclusions and implications}

In this paper we have shown that firms' pre-existence of subsidiaries has a positive impact on multinationals' collaborative agreements with local firms. Using evidence from the US and European electronics industry, we highlighted a relevant pattern of linkage creation that cannot be fully explained in the terms of the prevailing market entry literature. Consistently with this literature, we have shown that cooperation can be an important instrument to overcome cultural and geographic distance between countries, i.e. a flexible means to explore unknown market and technological opportunities. Contrary to the predictions of this literature, the setting up of extensive internal networks of subsidiaries appears to positively impact on linkage creation. On the one hand, subsidiary accumulation increases firms' absorptive capacity, thus improving firms' ability to search for, and evaluate technological and market opportunities, whose timely exploitation would increase their competitive advantage. On the other hand, acquaintance with local contexts enhances foreign firms' capacity to select and interact with local partners and institutions, as a means to gather further stimuli and innovative ideas, and to effectively exploit opportunities emerging from local contexts.

TNCs must deeply reorganise their structure in order to extract the highest potential value from the available network of affiliates (Zanfei 1996). Local subsidiaries need to be endowed with competencies, and with a relevant degree of autonomy in order to carry out their important role in the cooperative absorption of knowledge from local contexts. This

\footnotetext{
${ }^{14}$ As Dunning (1993 p.156) has noted: " More generally, it would appear that real wage costs are more likely to influence the mode of servicing developing than developed markets". Among OECD countries there is little evidence that this factor is a significant locational determinant (ibidem p.164)
} 
reorganisation is not costless, and competitive edges may heavily depend on how flexible internal organisations are face to these changes.

Important implications can be drawn also concerning the likely effects of multinational growth on local development. First, we showed that, in the case of LDCs, some previous inflow of capital can provide the basis for backward and forward linkages, potentially generating externalities for local (as well as foreign) economic activity. Second, we highlighted that linkages will not be stimulated by cultural and geographic distances per se, in the case of LDCs. Host countries must therefore pursue a combination of foreign capital attraction and of investments in infrastructures in general, and in human capital in particular. On the one hand, insufficient and/or inadequate human capital could determine a shortage of local manufacturing abilities as well as a lack of variety of goods in the local markets, which will increase the likelihood that multinationals displace local activities and will generate limited or no backward and forward linkages at all (Rodriguez-Clare 1996). This will in turn induce vicious circles of dependence from imports of key inputs, devaluation of national currency, and worsening terms of trade (Dunning and Cantwell 1988). We are not suggesting that host governments should limit their policies to economy-wide, functional interventions such as providing ample public education. As Bell and Pavitt (1993 pp.201-202) have emphasised, building a country's technological capabilities requires a wider set of industrial policy interventions aiming to favour explicit intra-firm training in the differentiated activities of design, production engineering, quality control, and R\&D.

On the other hand, efforts must be made to screen and select multinational presence. From this perspective, Rodriguez-Clare (1996 p.867) suggests that selective efforts should be directed towards those TNC activities that use intermediate goods more intensively, as these are likely to generate stronger linkages. Furthermore, the choice of areas in which foreign plants should be located is also relevant, as interactions with indigenous human capital is an essential feature of the entire " chain of reactions that build linkages". What must be made clear is that favouring the entry and root-taking of selected affiliates in selected regions and sectors is not the substitute for, but a fundamental premise to the formation of wide networks of collaborative activities between local firms and the affiliates themselves. 
Amin A. (1993) "The Globalization of the Economy: an Erosion of Regional Networks?" in Grabher G. (ed.)The Embedded Firm. On the Socioeconomics of Industrial Networks, Routledge, London (279-295)

Anderson E, Gatignon H. (1986) "Modes of Foreign Entry: Transaction Costs and Propositions”, Journal of International Business Studies, 17, pp. 1-26

Andersson U., Forsgren M. (1995), "Subsidiary Embeddedness and its Implication of Integration in the MNC", in Schiattarella R. (ed.) New Challenges for European and International Business, Proceedings of the 21st EIBA Conference, Urbino, 1012/12/95.

Arora A., Gambardella A. (1990) "Complementarity and External Linkages: the Strategies of the Large Firms in Biotechnology" The Journal of Industrial Economics, n.4, vol. 38 pp.361-379

Barro R., Lee J.W. (1993) “International Comparisons of Educational Attainment”, Journal of Monetary Economics, 32, 3, pp. 363-394.

Barro R., Lee J.W. (1996) "International Measures of Schooling Years and Schooling Quality”, American Economic Review, 86, 2, pp. 218-223.

Bell M., Pavitt K. (1993) " Technological Accumulation and Industrial Growth: Contrasts between Developed and Developing Countries" Industrial and Corporate Change, 2, 2, pp. $157-210$

Bilkey W.J . (1978) "An Attempted Integration of the Literature on the Export Behavior of Firms", Journal of International Business Studies, 9, pp. 33-46.

Blomstrom M., Kokko A. (1997) “How Foreign Investment Affects Host Countries”, Policy Research Working Paper N. 1745, The World Bank, International Economics Department, International Trade Division, March 1997.

Borensztein E., De Gregorio J., Lee J.W. (1998) “How Does Foreign Direct Investment Affect Economic Growth", Journal of International Economics, 45, pp.115-135

Buckley P.J., Casson M.C. (1988) “A Theory of Cooperation in International Business”, in Contractor F. and Lorange P. (eds) Cooperative Strategies in International Business, Lexington, D.C. Health and Co.

Bureth A., Wolff S., Zanfei A. (1997) " The Two Faces of Learning by Cooperating: The Evolution and Stability of Inter-Firm Agreements in the European Electronics Industry" Journal of Economic Behavior and Organisation, vol.32 pp.519-537

Cainarca G.C., Colombo M., Mariotti S. (1992) "greements Between Firms and the Technological Life Cycle Model: Evidence from Information Technologies" Research Policy, 21, (45-)

Cameron A.C., Trivedi P.K. (1998) Regression Analysis of Count Data, Cambridge University Press.

Cantwell (1991) "The Theory of Technological Competence and its Application to International Production" in McFetridge D.G. (ed.) Foreign Investment, Technology and Economic Growth, University of Calgary Press 
Cantwell J. (1995), “The Gobalisation of Technology: What Remains of the Product Cycle Model", Cambridge Journal of Economics, 19 (155-174)

Caves R., Mehra S. (1986) "Entry of Foreign Multinationals into U.S. Manufacturing Industries", in Porter (ed.) Competition in Global Industries, Harvard Business School Press

Chesnais F. (1996) Technological Agreements, Networks and Selected Issues in Economic Theory" in R.Coombs, A.Richards, P.P.Saviotti, V.Walsh (1996) Technological Collaboration. The Dynamics of Cooperation in Industrial Innovation, Elgar, Cheltenham, UK

Cohen W.M., Levinthal D.A. (1989), “Innovation and Learning: the Two Faces of R\&D”, Economic Journal, Vol. 99. pp.569-596.Cyert R.M., March J.G. (1963) A Behavioral Theory of the Firm, New York: Prentice Hall

D'Orazio A, Gambardella A, Pontiggia L., Torrisi S., Trenti S., Zanfei A. (1992) "Growth through External Linkages in the European Electronics Industry" in The Economics of Scientific and Technological Research in Europe, Final Report prepared for the EC, D.G. XII, December

Davidson W.H. (1980) "The Location of Foreign Direct Investment Activity: Country Characteristics and Experience effects", Journal of International Business Studies, 11, pp. 9-22.

Davidson W.H., McFetridge D.G. (1984) "International Technology Transactions and the Theory of the Firm", Journal of Industrial Economics, 32, pp. 353-364.

Davies H. (1977) “Technology Transfer through Commercial Transactions”, Journal of Industrial Economics, 26, December, pp.161-175

Dunning J.H. (1993) Multinational Enterprise and the Global Economy, Addison Wesley, Wokingham, England

Dunning J.H. (1995), "Reappreasing the Eclectic Paradigm in an Age of Alliance Capitalism”, Journal of International Business Studies, Third Quarter 1995 pp.461-491

Dunning J.H., Cantwell J . (1988), “The Changing Role of Multinational Enterprises in the Creation and Diffusion of Technology", in Dunning (ed.) Multinationals, Technology and Competitiveness, Unwin Hyman, London.

Duysters G., Hagedoorn J. (1996) "Internationalisation of Corporate Technology through Strategic Partnering: An Empirical Investigation" Research Policy, 20, n.5, pp.393-406

Ernst D. (1997) "From Partial to systemic Globalisation: International Production Networks in the Electronics Industry" BRIE Working Paper n. 98, Berkeley Roundtable on the International Economy, University of California at Berkeley

Flamm K. (1989) "Technological Advance and Costs: Computers vs. Communications" in R.W.Crandall, K.Flamm (eds.)Changing the Rules: Technological Change, International Competition in Communications, The Brookings Institution, Washington $\mathrm{DC}$

Freeman C. (1991) "Networks of Innovators: A Synthesis of Research Issues" Research Policy, vol.20, n.5 (499-514) 
Gambardella A., Torrisi S. (1998) "Does Technological Convergence Imply Convergence in Markets? Evidence from the Electronics Industry", Research Policy, 27, (5), pp. 445463

Gatignon H., Anderson E. (1988) “The Multinational Corporation's Degree of Control over Foreign Subsidiaries: An Empirical Test of Transaction Cost Explanation”, Journal of Law, Economics, and Organization, IV, 2, Fall 1988, pp. 305-336.

Ghoshal S., Bartlett C.A. (1990), “The Multinational Corporation as an Interorganizational Network", Academy of Management Review, Vol. 15, n. 4, pp. 603-625

Gomez-Casseres B. (1989) "Ownership Structures of Foreign Subsidiaries”, Journal of Economic Behavior and Organization, 2, pp. 1-25

Granovetter M. (1985) "Economic Action and Social Structure: the Problem of Embeddedness" American Journal of Sociology, v.91, n.3 (481-510)

Greene W.H. (1997) Econometric Analysis, Prentice Hall, 3rd Edition

Hausman J.A., Hall B.H., Griliches Z. (1984) "Econometric Models for Count Data with an Application to the Patents-R\&D Relationship" Econometrica, 52, pp.909-938

Hennart J . F . (1988) “A transaction Cost Theory of Equity J oint Ventures”, Strategic Management Journal, 9, pp. 361-374.

Hennart J.F., Larimo J . (1998) “The Impact of Culture on Strategy of Multinational Enterprises: Does National Origin Affect Ownership Decisions?", Journal of International Business Studies, 29, 3, Third Quarter 1998, pp. 515-538.

Hirschman A.O. (1958) The Strategy of Economic Development, Yale University, New Haven

Hladik K.J . (1985) International Joint Ventures. An Economic Analysis of US-Foreign Business Partnerships, Springer-Verlag, New York

Hofstede G. (1980) Culture's Consequences: International Differences in Work-related Values, Beverly Hills, SAGE.

JETRO (1989) Current Management Structure of Japanese Manufacturing Enterprises in Europe, $5^{\text {th }}$ Survey Report, Tokyo, JETRO.

Jo S.H. (1980) "Direct Foreign Private Investment", in Chong Kee Park (ed.) Macroeconomic and Industrial Development in Korea, Korea Development Institute, Seoul, pp. 129182.

Johanson J., Vahlne J.E. (1977) "The Internationalisation Process of a Firm - A Model of Knowledge Development and Increasing Market Commitment", Journal of International Business Studies, 8, pp. 23-32..

Kobrin S. (1976) “The Environmental Determinants of Foreign Direct Investment: An ExPost Empirical Analysis”, Journal of International Business Studies, VI, pp. 29-42.

Kogut B., Singh H. (1988) "The Effect of National Culture on the Choice of Entry Mode", Journal of International Business Studies, 19, pp. 411-432..

Kogut B., Zander U. (1993) "Knowledge of the Firm and the Evolutionary Theory of the Multinational Corporation", Journal of International Business Studies, 24, pp. 625.645. 
Lall S. (1978) "Transnationals, Domestic Enterprises and Industrial Structure in Host LDCs: A Survey", Oxford Economic Papers, 30, 2, pp. 217-248.

Lim L., Pang E.F. (1982) "Vertical Linkages and Multinational Enterprises in Developing Countries", World Development, 10, pp. 585-595.

Malerba F., Torrisi S. (1992) "Internal Capabilities and External Networks in Innovative Activities. Evidence from the Software Industry" Economics of Innovation and New Technology, vol.2 pp.49-71

McAlesee D., McDonald D. (1978) "Employment Growth and the Development of Linkages in Foreign Owned and Domestic Manufacturing Enterprises", Oxford Bulletin of Economics and Statistics, 40, pp. 321-339.

Mowery D.C. (Ed.) (1988) International Collaborative Ventures in US Manufacturing, Ballinger, Cambridge, Mass.

Mutinelli M., Piscitello L. (1998) “The Entry Mode Choice of MNEs: An Evolutionary Approach" Research Policy, 27, pp.491-506

Nelson R., Winter S. (1982) “An Evolutionary Theory of Economic Change”, Harvard University Press, Cambridge, MA.

OECD (1986) Technical Cooperation Agreements Between Firms: Some Initial Data and Analysis, DSTI, Technical Report, DSTI/SPR/86.20, Paris, May

Papanastassiou M., Pearce R.D. (1990) "Host Country Characteristics and the Sourcing Behaviour of UK Manufacturing Industry". University of Reading, Department of Economics, Discussion Papers in International Investment and Business Studies, Series B, Vol II, No. 140.

Pearce R.D. (1997) Global Competition and Technology, McMillan Press Ltd, London

Predicasts Company Thesaurus, Annual Edition (1983 and 1991), Predicasts Inc., Cleveland, Ohio

Predicasts F\&S Index of Corporate Change, Annual edition (1984-1992), Predicasts Inc., Cleveland, Ohio

Rodiguez-Clare A. (1996) "Multinationals, Linkages, and Economic Development" The American Economic Review, Vol. 86 N. 4 pp.852-873

Ronen S., Shenkar O. (1985) "Clustering Countries on Attitudinal Dimensions: A Review and a Synthesis", Academy of Management Review, 10, pp. 435-454.

Rosenberg N. (1990), “Why Do Firms Do Basic Research (With Their Own Money)?”, Research Policy, Vol. 19, pp.165-174

Rosenfeld S.A. (1996) " Does Cooperation Enhance Competitiveness? Assessing the Impacts of Inter-firm Collaboration", Research Policy, Vol. 25, (247-263).

Rosenzweig P., Nohria N. (1994), "Influences of Human Resource Management in Multinational Corporations”, Journal of International Business Studies, 4 (715-251)

Sachwald F. (1998) "Cooperative Agreements and the Theory of the Firm: Focussing on Barriers to Change", Journal of Economic Behavior and Organization, 35, 203-225 
Steinmueller W.E. (1991) " The Economics of Production and Distribution og User-Specific Information via Digital Networks" in C.Antonelli (ed.) The Economics of Information Networks, North Holland, Amsterdam

Steinmueller W.E. (1992) " The Economics of Flexible Integrated Circuit Manufacturing Technology" Review of Industrial Organisation, 7, pp.327-349

Stopford J.M., Wells jr. L.T. (1972) Managing the Multinational Enterprise: Organisation of the Firm and Ownership of Subsidiaries, New York, Basic Books

Swedenborg (1979) The Multinational Operation of Swedish Firms: An Analysis of Determinants and Effects, Stockholm: Industriens Utrednings Institut.

Teece (1986a) "Transaction Costs Economics and the Multinational Enterprise: An Assessment" Journal of Economic Behavior and Organization, 7 pp.21-45

Teece D.J. (1986b), "Profiting from Technological Innovation: Implication for Integration, Collaboration, Licensing and Public Policy”, Research Policy, Vol. 15, pp.285-305.

Teece D.J. (1992) “Competition, Cooperation and Innovation. Organizational Arrangements for Regimes of Rapid Technological Progress" Journal of Economic Behaviour and Organization, vol. 18, n.1 (1-26)

UN (1995) UN Statistical Yearbook $39^{\text {th }}$ Edition, Berman Press, New York

UNCTAD (1997) World Investment Report 1997: Transnational Corporations, Market Structure and Competition Policy, United Nations, New York

Vaccà S. (1994) "Le imprese transnazionali tra sistemi locali e sistemi globali" Economia e politica industriale $\mathrm{n} .84$ (23-62)

Vaccà S., Zanfei A. (1995), "Capturing Value from Local Contexts: The Decentralization of Decisions within Transnational Corporations", in Schiattarella R. (ed.) New challenges for European and International Business, Proceedings of the 21st EIBA Conference, Urbino, December 10-12.

Zander I. (1998) " The Evolution of Technological Capabilities in the Multinational Corporation - Dispersion, Duplication and Potential Advantages from Multinationality" Research Policy, vol.27, n.1 (17-35)

Zanfei A. (1993) "Patterns of Collaborative Innovation in the US Telecommunications Industry After Divestiture" Research Policy, 22 pp.309-325

Zanfei A. (1996), "Technology and the Changing Organization of Transnational Firms", International Workshop on: Learning and Embeddedness: Evolving Transnational Firm Strategies in Europe, EMOT-ESF, University of Durham, 27-29 J une 1996.

Zejan M. (1990) "New ventures or acquisitions: The choice of Swedish multinational enterprises", Journal of Industrial Economics, 38, pp. 349-355. 
Table 1. Variable list and description

\begin{tabular}{|c|c|c|c|}
\hline $\begin{array}{l}\text { VARIABLE } \\
\text { NAME }\end{array}$ & \multicolumn{2}{|r|}{ DESCRIPTION } & SOURCE \\
\hline i & \multicolumn{2}{|c|}{ Company (see Appendix 1) } & \\
\hline $\mathbf{n}$ & \multicolumn{2}{|c|}{ Home country of firm i } & \\
\hline $\mathbf{k}$ & \multicolumn{2}{|c|}{ Country of destination } & \\
\hline \multicolumn{3}{|c|}{ DEPENDENT VARIABLES } & \\
\hline AG8495ik & \multicolumn{2}{|r|}{$\begin{array}{l}\text { Number of international agreements (sum of Joint Ventures and Non-Equity Agreements) of } \\
\text { firm i in country k }\end{array}$} & $\begin{array}{l}\text { ARGO (see } \\
\text { Appendix 1) }\end{array}$ \\
\hline FDI8495ik & \multicolumn{2}{|r|}{ Number of foreign direct investment operations of firm i in country $\mathrm{k}$} & $\begin{array}{l}\text { ARGO (see } \\
\text { Appendix 1) }\end{array}$ \\
\hline LIC8495ik & \multicolumn{2}{|r|}{ Number of sales of patented technology from firm i to parties originating from country $\mathrm{k}$} & $\begin{array}{l}\text { ARGO (see } \\
\text { Appendix 1) }\end{array}$ \\
\hline \multicolumn{3}{|c|}{ EXPLANATORY VARIABLE } & \\
\hline \multicolumn{3}{|c|}{ Measure of TNC experience in host countries } & \\
\hline SUBS83ik & \multicolumn{2}{|r|}{ Number of "first and second level" foreign subsidiaries of firm i in country k in 1983} & $\begin{array}{l}\text { Predicasts and } \\
\text { ARGO (see } \\
\text { Appendix 1) }\end{array}$ \\
\hline \multicolumn{3}{|c|}{ OTHER CONTROL INDEPENDENT VARIABLES } & \\
\hline \multicolumn{3}{|c|}{ Company variables } & \\
\hline RD_INT & \multicolumn{2}{|r|}{ R\&D intensity (R\&D/Sales) of firm i } & Fortune \\
\hline$\overline{\text { SAL }_{\mathrm{i}}}$ & \multicolumn{2}{|r|}{ Sales of firm i, 1983 (billions of US\$) } & Fortune \\
\hline $\mathrm{MULTI}_{\mathbf{i}}$ & \multicolumn{2}{|r|}{$\begin{array}{l}\text { Measure of multinationality of firm i. Calculated as the number of foreign countries were firm i } \\
\text { had at least one subsidiary in } 1983 \text {. }\end{array}$} & $\begin{array}{l}\text { Predicasts } \\
\text { Company } \\
\text { Thesaurus }\end{array}$ \\
\hline DUSA $_{\mathbf{i}}$ & \multicolumn{2}{|r|}{ Dummy which takes value 1 if the home country of firm $i$ is ithe US } & \\
\hline \multicolumn{3}{|c|}{ Recipient country variables } & \\
\hline HUMAN $_{k}$ & \multicolumn{2}{|r|}{ Average schooling years in 1980 in the total population over 25 (divided by 100) } & Barro-Lee (1993) \\
\hline GDP $_{k}$ & \multicolumn{2}{|r|}{ Real GDP per capita in country k, 1980 (millions of current US\$) } & $\begin{array}{l}\text { Penn World } \\
\text { Tables Mark } 5.6\end{array}$ \\
\hline POP $_{k}$ & \multicolumn{2}{|r|}{ Total population of country k, 1980 (millions of inhabitants) } & $\begin{array}{l}\text { Penn World } \\
\text { Tables Mark } 5.6\end{array}$ \\
\hline GGDP $_{\mathbf{k}}$ & \multicolumn{2}{|r|}{ Annual Growth Rate of per capita GDP of country k, 1980-84 } & $\begin{array}{l}\text { Penn World } \\
\text { Tables Mark } 5.6\end{array}$ \\
\hline EVA k & \multicolumn{2}{|r|}{$\begin{array}{l}\text { Value Added in Electrical Machinery (ISIC 383) in country k as a share of Value Added in } \\
\text { Manufacturing (ISIC 300) in the same country (average 1980-87, current US } \$ \text { ) }\end{array}$} & UNIDO (1995) \\
\hline $\mathrm{OWTI}_{\mathbf{k}}$ & \multicolumn{2}{|r|}{ Own-import weighted tariff rates on intermediate inputs and capital goods } & Barro-Lee (1993) \\
\hline \multicolumn{3}{|c|}{ Relation specific country variables } & \\
\hline \multicolumn{2}{|l|}{ EXELE nk } & $\begin{array}{l}\text { Export of electronics products (CITC } 75,77,764) \text { from firm's i home country to country k } \\
\text {, as a share of total export of electronic products of the home country }\end{array}$ & $\begin{array}{l}\text { OECD Foreign } \\
\text { Trade by } \\
\text { Commodities }\end{array}$ \\
\hline \multicolumn{2}{|c|}{ WAGELE nk } & $\begin{array}{l}\text { Relative electronics wage differentials: average wages in electronics paid in the host } \\
\text { county as a share of average wages in electronics paid in the home country }\end{array}$ & UNIDO \\
\hline \multicolumn{2}{|c|}{ CULTDISTnk } & $\begin{array}{l}\text { Measure of cultural differences between the home and host country. It is calculated as } \\
\text { the arithmetic average of the squared deviation of home scores for each of the } 4 \\
\text { Hofstede's dimensions of cultural identity (power distance, individualism, uncertainty } \\
\text { avoidance and masculinity) from the corresponding score for the host country, corrected } \\
\text { for the overall variance of each of these dimensions. The higher the score, the greater the } \\
\text { cultural distance between home and host country. }\end{array}$ & $\begin{array}{l}\text { Hofstede (1980), } \\
\text { Kogut and Sigh } \\
\text { (1988) }\end{array}$ \\
\hline \multicolumn{2}{|c|}{ DISTANCE $_{n k}$} & $\begin{array}{l}\text { Takes value } 1 \text { if the host country } \mathrm{k} \text { is in the same geographic region of the home country } \\
\text { of firm } \mathrm{i} ; 2 \text { if it is in region which is bordering to the home region; } 3 \text { if it is not bordering. } \\
\text { For the } 13 \text { European firms, DISTANCE=1 for operations with firms from other European } \\
\text { countries; }=2 \text { with firms from Eastern Europe/Africa and Middle East; }=3 \text { with firms from } \\
\text { other regions; for the } 19 \text { North American firms, DISTANCE }=1 \text { when the recipient country } \\
\text { is in North America; }=2 \text { when it is in Latin America and =3 in all the other cases). }\end{array}$ & $\begin{array}{l}\text { Davidson and } \\
\text { McFetridge } \\
\text { (1984) use the } \\
\text { same criteria }\end{array}$ \\
\hline
\end{tabular}


Table 2a. Descriptive Statistics - Whole Sample

\begin{tabular}{lccccccc}
\hline \multicolumn{1}{c}{ Variable } & Mean & $\begin{array}{c}\text { Std. } \\
\text { Dev }\end{array}$ & Skew. & Kurt. & Min & Max & Cases \\
\hline \multicolumn{1}{c}{ Dependent } & & & & & & & \\
AG8495 & 0.647 & 2.5042 & 8.7 & 111.8 & 0 & 44 & 1824 \\
FDI8495 & 0.246 & 1.1557 & 11.3 & 184.8 & 0 & 25 & 1824 \\
LIC8495 & 0.093 & 0.4952 & 8.7 & 105.7 & 0 & 8 & 1824 \\
$\quad$ Independent & & & & & & & \\
SUBS83 & 0.501 & 1.8923 & 8.9 & 114.0 & 0 & 35 & 1824 \\
RD_INT & 0.076 & 0.0311 & 0.0 & 2.5 & 0.0093 & 0.146 & 1824 \\
SAL & 6.463 & 8.7076 & 2.7 & 9.9 & 0.1110 & 40.18 & 1824 \\
MULTI & 11.281 & 5.2349 & 0.9 & 3.7 & 4 & 26 & 1824 \\
DUSA & 0.593 & 0.4913 & -0.4 & 1.1 & 0 & 1 & 1824 \\
HUMAN & 0.063 & 0.0276 & 0.0 & 2.0 & 0.0050 & 0.121 & 1824 \\
GDP & 5.472 & 3.8186 & 1.4 & 6.7 & 0.4880 & 21.779 & 1824 \\
POP & 0.059 & 0.1574 & 4.7 & 25.1 & 0.0004 & 0.981 & 1824 \\
GGDP & 0.057 & 0.0384 & -1.9 & 9.1 & -0.108 & 0.128 & 1824 \\
EVA & 1.519 & 10.825 & 7.3 & 55.0 & 0.0008 & 82.503 & 1824 \\
& & 2 & & & & & \\
OWTI & 0.119 & 0.1768 & 5.5 & 37.3 & 0 & 1.319 & 1824 \\
EXELE & 0.017 & 0.0349 & 8.3 & 150.2 & 0 & 0.801 & 1824 \\
WAGELE & 0.468 & 0.3626 & 1.1 & 4.0 & 0.0198 & 1.898 & 1824 \\
CULTDIST & 43.662 & 29.387 & 0.7 & 2.6 & 0.4829 & 155.45 & 1824 \\
DISTANCE & 2.546 & 0.7050 & -1.2 & 3.1 & 1 & 3 & 1824 \\
\hline
\end{tabular}

Table 2b. Descriptive Statistics - LDC Sample

\begin{tabular}{lccccccc}
\hline \multicolumn{1}{c}{ Variable } & Mean & $\begin{array}{c}\text { Std. } \\
\text { Dev }\end{array}$ & Skew. & Kurt. & Min & Max & Cases \\
\hline \multicolumn{1}{c}{ Dependent } & & & & & & & \\
AG8495 & 0.373 & 1.460 & 8.5 & 104.5 & 0 & 24 & 1056 \\
FDI8495 & 0.120 & 0.533 & 6.9 & 71.8 & 0 & 8 & 1056 \\
LIC8495 & 0.065 & 0.354 & 7.4 & 72.5 & 0 & 5 & 1056 \\
Independent & & & & & & & \\
SUBS83 & 0.095 & 0.352 & 4.3 & 24.8 & 0 & 3 & 1056 \\
RD_INT & 0.076 & 0.031 & 0.0 & 2.5 & 0.0093 & 0.146 & 1056 \\
SAL & 6.463 & 8.709 & 2.7 & 9.9 & 0.111 & 40.18 & 1056 \\
MULTI & 11.281 & 5.236 & 0.9 & 3.7 & 4 & 26 & 1056 \\
DUSA & 0.593 & 0.491 & -0.4 & 1.1 & 0 & 1 & 1056 \\
HUMAN & 0.051 & 0.024 & 0.3 & 2.4 & 0.005 & 0.107 & 1056 \\
GDP & 3.861 & 3.825 & 3.2 & 15.0 & 0.488 & 21.779 & 1056 \\
POP & 0.082 & 0.201 & 3.5 & 14.6 & 0.0006 & 0.981 & 1056 \\
GGDP & 0.051 & 0.048 & -1.2 & 5.3 & -0.108 & 0.128 & 1056 \\
EVA & 0.072 & 0.098 & 3.9 & 19.3 & 0.002 & 0.566 & 1056 \\
OWTI & 0.165 & 0.217 & 4.5 & 24.1 & 0 & 1.319 & 1056 \\
EXELE & 0.008 & 0.016 & 9.3 & 165.6 & 0 & 0.334 & 1056 \\
WAGELE & 0.254 & 0.182 & 1.6 & 6.8 & 0.019 & 1.244 & 1056 \\
CULTDIST & 52.048 & 29.288 & 0.5 & 2.1 & 6.015 & 146.87 & 1056 \\
DISTANCE & 2.682 & 0.465 & -0.8 & 1.6 & 2 & 3 & 1056 \\
\hline
\end{tabular}


Table 3 - Determinants of inter-firm linkages (Whole Sample): Negative Binomial Estimation, 1984-1995

\begin{tabular}{|c|c|c|c|c|c|c|}
\hline & \multicolumn{2}{|c|}{ AG8495 } & \multicolumn{2}{|c|}{ FDI8495 } & \multicolumn{2}{|c|}{ LIC8495 } \\
\hline Variable & Estimate & t-ratio & Estimate & t-ratio & Estimate & t-ratio \\
\hline Constant & -5.562 & $(-12.07) * *$ & -4.281 & $(-5.12) * *$ & -6.540 & $(-6.60) * *$ \\
\hline SUBS83 & 0.103 & $(2.51) * *$ & 0.096 & $(1.55)$ & 0.059 & $(0.97)$ \\
\hline RD_INT & 8.905 & $(4.20) * *$ & 5.452 & $(1.40)$ & 6.605 & $(1.25)$ \\
\hline SAL & 0.039 & $(5.33) * *$ & 0.042 & $(2.98) * *$ & 0.038 & $(2.44)^{*}$ \\
\hline MULTI & 0.048 & $(3.61)^{* *}$ & 0.013 & $(0.62)$ & -0.015 & $(-0.51)$ \\
\hline DUSA & -0.416 & $(-2.05)^{*}$ & -0.815 & $(-2.85) * *$ & -0.598 & $(-1.86)$ \\
\hline HUMAN & 6.011 & $(1.95)^{*}$ & 7.678 & $(1.67)$ & 0.785 & $(0.10)$ \\
\hline GDP & 0.102 & $(2.82) * *$ & 0.108 & $(1.97)^{*}$ & 0.052 & $(0.39)$ \\
\hline POP & 3.736 & $(6.95) * *$ & 2.103 & $(1.75)$ & 2.970 & $(3.77)^{* *}$ \\
\hline GGDP & 13.759 & $(5.10) * *$ & 7.743 & $(1.80)$ & 14.940 & $(2.48)^{*}$ \\
\hline EVA & 0.013 & $(2.91) * *$ & -0.013 & $(-1.47)$ & 0.014 & (1.87) \\
\hline OWTI & -0.111 & $(-0.25)$ & -0.179 & $(-0.22)$ & 0.107 & $(0.17)$ \\
\hline EXELE & 15.745 & $(7.42) * *$ & 13.691 & $(3.75) * *$ & 13.512 & $(3.52) * *$ \\
\hline WAGELE & 0.075 & $(0.29)$ & -0.077 & $(-0.19)$ & 0.534 & $(0.67)$ \\
\hline CULTDIST & 0.006 & $(2.70) * *$ & 0.005 & $(1.44)$ & 0.003 & $(0.63)$ \\
\hline DISTANCE & 0.060 & $(0.50)$ & -0.117 & $(-0.82)$ & 0.405 & $(2.13)^{*}$ \\
\hline$\alpha$ & 2.390 & $(10.28)^{* *}$ & 4.888 & $(7.37) * *$ & 3.722 & $(3.58) * *$ \\
\hline Sample size & 1824 & & 1824 & & 1824 & \\
\hline Chi Squared & & $781.965 * *$ & & $477.314 * *$ & & $70.686 * *$ \\
\hline Log-L & -1286.189 & & -823.498 & & -430.156 & \\
\hline Log-LPsn & -1677.172 & & -1062.155 & & -465.499 & \\
\hline LR Test & & $781.966 * *$ & & $477.314 * *$ & & $70.686 * *$ \\
\hline
\end{tabular}

* significant at $\mathrm{p}=.05$ (two tailed); ** significant at $\mathrm{p}=.05$ (two tailed)

$\alpha$ is the estimate of the overdispersion parameter

The Chi Squared statistics tests the null hp. That all the parameter estimates are equal to zero

Table 4 - Determinants of inter-firm linkages (LDC Sample): Negative Binomial Estimation, 1984-1995

\begin{tabular}{lrlrlrl} 
& \multicolumn{2}{c}{ AG8495 } & \multicolumn{2}{c}{ FDI8495 } & \multicolumn{2}{c}{ LIC8495 } \\
\hline \multicolumn{1}{c}{ Variable } & Estimate & t-ratio & Estimate & t-ratio & Estimate & t-ratio \\
\hline Constant & -5.689 & $(-7.19)^{* *}$ & -5.991 & $(-3.47)^{* *}$ & -4.853 & $(-2.73)^{* *}$ \\
SUBS83 & 0.549 & $(2.24)^{* *}$ & 0.445 & $(1.26)$ & 0.142 & $(0.21)$ \\
RD_INT & 7.622 & $(2.12)^{*}$ & 15.875 & $(2.43)^{*}$ & 10.283 & $(0.98)$ \\
SAL & 0.033 & $(2.95)^{* *}$ & 0.054 & $(2.73)^{* *}$ & 0.045 & $(1.81)$ \\
MULTI & 0.080 & $(3.65)^{* *}$ & 0.040 & $(1.13)$ & -0.010 & $(-0.19)$ \\
DUSA & -0.095 & $(-0.33)$ & -1.068 & $(-2.80)^{* *}$ & -0.441 & $(-0.76)$ \\
HUMAN & 24.262 & $(4.63)^{* *}$ & 7.867 & $(0.87)$ & 6.864 & $(0.51)$ \\
GDP & 0.113 & $(2.04)^{*}$ & 0.061 & $(0.83)$ & 0.038 & $(0.17)$ \\
POP & 3.184 & $(6.60)^{* *}$ & 0.963 & $(1.02)$ & 2.874 & $(2.66)^{* *}$ \\
GGDP & 14.739 & $(4.03)^{* *}$ & 3.077 & $(0.57)$ & 20.175 & $(2.03)^{*}$ \\
EVA & 0.055 & $(0.04)$ & -1.424 & $(-0.49)$ & 3.280 & $(1.83)$ \\
OWTI & 1.109 & $(2.42)^{*}$ & 0.447 & $(0.56)$ & 0.531 & $(0.63)$ \\
EXELE & 23.573 & $(4.57)^{* *}$ & 22.330 & $(2.65)^{* *}$ & 12.265 & $(0.85)$ \\
WAGELE & 0.284 & $(0.37)$ & -4.495 & $(-2.91)^{* *}$ & 0.265 & $(0.11)$ \\
CULTDIST & 0.005 & $(1.18)$ & 0.016 & $(2.38)^{*}$ & 0.004 & $(0.35)$ \\
DISTANCE & -0.620 & $(-2.13)^{*}$ & 0.257 & $(0.63)$ & -0.722 & $(-1.22)$ \\
$\alpha$ & 1.844 & $(5.55)^{* *}$ & 3.152 & $(2.86)^{* *}$ & 5.270 & $(2.23)^{*}$ \\
\hline Sample size & 1056 & & 1056 & & 1056 & \\
Chi Squared & \multicolumn{2}{c}{$156.403 * *$} & & $47.957 * *$ & & $38.612 * *$ \\
Log-L & -559.916 & & -301.786 & & -204.889 & \\
Log-LPsn & -638.118 & & -325.764 & & -224.195 & \\
LR Test & \multicolumn{2}{c}{$156.404 * *$} & & $47.956 * *$ & & $38.612 * *$ \\
\hline
\end{tabular}

* significant at $\mathrm{p}=.05$ (two tailed); ** significant at $\mathrm{p}=.05$ (two tailed)

$\alpha$ is the estimate of the overdispersion parameter

The Chi Squared statistics tests the null hp. that all the parameter estimates are equal to zero 
Appendix 1 - The A.R.G.O database and the list of sample firms

ARGO (Agreements, Restructuring and Growth Operations) is a database jointly built by Università di Urbino and LIUC, Castellanza, in collaboration with IEFE-Università Bocconi, Milan. The source is: Predicasts F\&S Index, which covers a wide range of journals and newspapers published in different countries and different languages

ARGO collects information on more than 5000 internal growth operations (New Subsidiaries, Sale of existing Subsidiaries, and Divestitures) as well as external growth operations (Joint ventures, Minority Participations, Acquisitions, and Strategic Alliances) and restructuring of the 32 largest US and European companies listed by Fortune 500 in the electronic sectors, over the 1984-95 period. In the list below, ARGO companies are classified by country of origin, and by core business. The source for sales data is Fortune 500.

\begin{tabular}{|c|c|c|c|c|c|}
\hline & Company Name & Acronym & $\begin{array}{c}\text { Country } \\
\text { of } \\
\text { Origin }\end{array}$ & $\begin{array}{c}\text { Core } \\
\text { Business }\end{array}$ & $\begin{array}{c}\text { Sales in mil } \\
\text { US\$ } 1990\end{array}$ \\
\hline 1 & Amp & amp & 1usa & semi & 3044 \\
\hline 2 & Apple & apple & 1usa & $\mathrm{cmp}$ & $5372^{\wedge}$ \\
\hline 3 & AT\&T & att & 1usa & tlc & 37285 \\
\hline 4 & Bull & bull & $4 \mathrm{fra}$ & $\mathrm{cmp}$ & $6465^{\wedge}$ \\
\hline 5 & Control Data Corp & $\mathrm{cdc}$ & 1usa & $\mathrm{cmp}$ & $2952^{\wedge}$ \\
\hline 6 & Alcatel (CGE) & cge & $4 \mathrm{fra}$ & tlc & 26451 \\
\hline 7 & Compaq & compaq & 1usa & $\mathrm{cmp}$ & $2876^{\wedge}$ \\
\hline 8 & Digital Equipment & dec & 1usa & $\mathrm{cmp}$ & $12937^{\wedge}$ \\
\hline 9 & LM Ericsson & erics & 5swe & tlc & 7723 \\
\hline 10 & $\mathrm{Gec}$ & gec & $4 \mathrm{uk}$ & oel & 16842 \\
\hline 11 & Honeywell & honey & 1usa & $\mathrm{cmp}$ & $6309^{\wedge}$ \\
\hline 12 & Hewlett Packard & $\mathrm{hp}$ & 1usa & oel & $11899^{\wedge}$ \\
\hline 13 & $\begin{array}{l}\text { International Business } \\
\text { Machines (IBM) }\end{array}$ & $\mathrm{ibm}$ & 1usa & $\mathrm{cmp}$ & $62710^{\wedge}$ \\
\hline 14 & Intel & intel & 1usa & semi & 3921 \\
\hline 15 & Motorola & moto & 1usa & $\mathrm{cmp}$ & 10885 \\
\hline 16 & $\mathrm{Ncr}$ & $\mathrm{ncr}$ & 1usa & $\mathrm{cmp}$ & $5956^{\wedge}$ \\
\hline 17 & Nixdorf Computer & nixd & 4wge & $\mathrm{cmp}$ & $2793^{\wedge}$ \\
\hline 18 & Nokia & nokia & 5 fin & nonel & 5790 \\
\hline 19 & Northern Telecom & $\mathrm{nt}$ & 2can & tlc & 6769 \\
\hline 20 & Olivetti & oli & 4 ita & $\mathrm{cmp}$ & $6584^{\wedge}$ \\
\hline 21 & Philips & phil & 4net & oel & 30623 \\
\hline 22 & Racal Electronics & racal & $4 \mathrm{uk}$ & tlc & 3524 \\
\hline 23 & Raytheon & rayt & 1usa & nonel & 9268 \\
\hline 24 & Siemens & siem & 4wge & oel & 39100 \\
\hline 25 & $\mathrm{Stc} / \mathrm{ICL}$ & stc & $4 \mathrm{uk}$ & $\mathrm{cmp}$ & $4265^{\wedge}$ \\
\hline 26 & Thomson & thom & $4 \mathrm{fra}$ & oel & 13813 \\
\hline 27 & Thorn Emi & thorn & $4 u k$ & oel & 6501 \\
\hline 28 & Texas Instruments & ti & 1usa & semi & 6567 \\
\hline 29 & Trw & trw & 1usa & nonel & 8169 \\
\hline 30 & Unisys & unis & 1usa & nonel & $10097^{\wedge}$ \\
\hline 31 & Wang Laboratories & wang & 1usa & $\mathrm{cmp}$ & $2697^{\wedge}$ \\
\hline 32 & Zenith & zen & 1usa & oel & 1405 \\
\hline
\end{tabular}

$\wedge 1989$ data

tlc = telecommunications equipment and/or services: SIC 3661-3669, and SIC4800 (excluding 4830 and 4843)

$\mathbf{c m p}=$ computers and office equipment and software:SIC 3571-3579 and 7371-7379

semi $=$ semiconductors and electronic components SIC3674

oel = other electronics: SIC 3500, 3600, and 3810-3870

nonel = non electronic sectors: other SIC codes not included in classes 1 through 4 


\section{Appendix 2 - The negative binomial regression model}

Several formulations of the negative binomial regression model have been proposed. The most common implementation is the following (Greene 1997):

$$
E\left[y_{i k} \mid \mathbf{x}_{i k}\right]=\mu_{i k}=\exp \left(\beta^{\prime} \mathbf{x}_{i k}+\varepsilon_{i k}\right)=\lambda_{i k} \exp \left(\varepsilon_{i k}\right)
$$

Where $\beta$ is the vector of parameters, $y_{i k}$ is our dependent variable, $\mathrm{x}_{\mathrm{ik}}$ is the vector of regressors and $\exp (\varepsilon)$ is a gamma distributed disturbance with mean 1.0 and variance $1 / \alpha$. The introduction of this distrurbance allows the variance to differ from the mean ${ }^{15}$. The resulting conditional probability distribution is

$$
\operatorname{Pr}\left(y=y_{i k} \mid \varepsilon\right)=\frac{e^{-\lambda_{i k} \exp (\varepsilon)} \lambda_{i k} y_{i k}}{y_{i k} !}, y=0,1,2, \ldots \ldots
$$

Integrating $\varepsilon$ out of this expression produces the unconditional ditribution of $y_{i k}$.

$$
\operatorname{Pr}\left(y=y_{i k}\right)=\frac{\Gamma\left(\theta+y_{i k}\right)}{\left[\Gamma(\theta) y_{i k} !\right] u_{i}^{\theta}\left(1-u_{i}\right)^{y i k}} \text {, where } u_{i k}=\frac{\theta}{\left(\theta+\lambda_{i k}\right)} \text { and } \theta=1 / \alpha^{16}
$$

After some algebra (see Cameron and Trivedi 1998; Greene, 1997) we obtain the loglikelihood function which have been used for estimation:

$$
\ln L_{i k}=\ln \operatorname{Pr}\left(y_{i k}=j\right)=\sum_{m=0}^{j-1} \ln (\theta+m)-\ln y !+\theta \ln u_{i k}+y_{i k} \ln \left(1-u_{i k}\right)
$$

It is worth noting that in the present formulation, the coefficient $\beta j$ equals the proportionate change in the conditional mean when the $f^{\text {th }}$ regressor change by one unit. This follows from the fact that $\frac{\partial E[y \mid \mathbf{x}]}{\partial x_{j}}=\beta_{j} \exp \left(\beta^{\prime} \mathbf{x}+\varepsilon\right)=\beta_{j} E[y \mid \mathbf{x}]$, and hence $\beta_{j}=\frac{\partial E[y \mid \mathbf{x}]}{\partial x_{j}} \frac{1}{E[y \mid \mathbf{x}]}$ which, in fact, is a semielasticity. Then, the parameter estimate $\hat{\beta}_{j}$ indicates an effect of the ${ }^{\text {th }}$ regressor $x_{j}$ on the dependent variable $y$, which is not free of the unit of measure of $x$; One method to solve this problem is to scale by the sample mean of $x_{j}$; and use $\xi_{j}=\hat{\beta}_{j} \bar{x}=\frac{\partial E[y \mid \mathbf{x}]}{\partial x_{j}} \frac{\bar{x}}{E[y \mid \mathbf{x}]}$, which is a maesure of elasticity (Cameron and Trivedi, 1998). In tables 3 and 4 we present the estimated coefficients $\hat{\beta}_{j}$ 's. These are sufficient for most of our discussion. In order to obtain elasticities, one needs to multiply the coefficient by the sample mean of the independent variable (see the descriptive statisitcs in tables $2 a$ and $2 b$ ).

\footnotetext{
${ }^{15}$ In fact, the NB arises an extension of the Poisson regression model, which is carachterized by the equality of the conditional mean and variance (defined as equidispersion):

$\mathrm{E}\left[y_{i k} \mid \mathbf{x}_{i k}\right]=\operatorname{Var}\left[y_{i k} \mid \mathbf{x}_{i k}\right]=\lambda_{i k}=\exp \left(\beta^{\prime} \mathbf{x}_{i k}\right)$.

${ }^{16}$ It is easy to show that $\operatorname{Var}\left(y_{i k} \mid \mathbf{x}_{i k}\right)=E\left(y_{i k} \mid \mathbf{x}_{i k}\right)\left[1+\alpha E\left(y_{i k} \mid \mathbf{x}_{i k}\right)\right]$, and $\alpha$ measures the extent to which the variance is greater than the mean. For this reason, $\alpha$ is called the overdispersion parameter
} 